Nikolina Palašić

Sveučilište u Rijeci

nikolina.palasic@ffri.uniri.hr

Tihana Zbašnik

Sveučilište u Rijeci

tihana.zbasnik@gmail.com

\title{
Imperativnost između gramatičke zadanosti i komunikacijske uljudnosti
}

\begin{abstract}
Palašić Nikolina, Zbašnik Tihana, Imperativnost između gramatičke zadanosti i komunikacijske uljudnosti (Imperativeness in between Grammatical Givens and Communicative Politeness). "Poznańskie Studia Slawistyczne" 13. Poznań 2017. Publishing House of the Poznań Society for the Advancement of the Arts and Sciences, pp. 179-193. ISSN 2084-3011.

The paper focuses on the relation between imperatives and imperativeness, that is, between the imperative as a grammatical mood with a defined form and its assigned function, on the one hand, and imperativeness as a communicative value that can manifest itself through different morphosyntactic forms, on the other. In this sense, the function of imperatives is analysed in the context of the theory of speech acts. The analysis reveals that different imperative forms can be classified as different types of speech acts based on their various communicative roles. The theory of politeness dictates that directness, which is a basic feature of imperatives, should be avoided in polite communication. This is why we also focus on other morphosyntactic forms whose form indicates a reduced level of directness, but whose content still has the characteristics of imperatives.
\end{abstract}

KEYwORDS: imperative; imperativeness; speech act; politeness; communicative function

\section{Imperativ vs. imperativnost}

Kada govorimo o imperativnosti, moramo prije svega razgraničiti imperativ kao gramatičku kategoriju, koju obilježavaju određeni formalni kriteriji, te imperativ(nost) kao pragmatičku kategoriju koja nije strogo vezana uz formu izraza. Pod imperativom se kao gramatičkom kategorijom podrazumijeva zapovjedni glagolski način kojim se „cijela komunikativna perspektiva rečenice ili teksta usmjeruje na drugo lice" (Silić, Pranjković, 2005, 194). Kako vidimo, iz gramatičke perspektive imperativ nam služi za izricanje zapovijedi - uporabom imperativnih oblika obraćamo 
se sugovorniku zahtijevajući od njega da izvrši neku radnju (Zatvori prozor!) ili dajući mu do znanja da ga u pojedinoj situaciji - uporabom tzv. perifrastičnog oblika - smatramo posrednikom prenošenja zahtjeva za izvršenje neke radnje trećoj osobi (Neka on dođe u 12.). Imperativni oblik za 1. lice množine na isti način kao i u obraćanju sugovorniku u 2. licu poziva sugovornika na izvršenje kakve radnje, uz istovremenu naznaku da radnju namjerava izvršiti i govornik (Završimo sada!) ${ }^{1}$. Imperativ za prvo lice množine nameće, međutim, još neka pitanja. Ako isti primjer stavimo u konkretnu situaciju, recimo pisanje ispita, i pretpostavimo da profesor (koji ne piše ispit) u jednom trenutku kaže studentima Završimo sada!, možemo li i dalje tvrditi da se takav oblik odnosi na radnju koju i govornik i sugovornik zajedno vrše? Očigledno ne. Sličan primjer ono je što bi se iz pragmalingvističke perspektive moglo opisati kao uporaba tzv. ekskluzivnog $m i^{2}$, naime posebna oblika uporabe zamjenice za prvo lice množine u kojem govornik iz radnje sadržane u iskazu isključuje sugovornika. Takav primjer imperativnog oblika možemo vidjeti u rečenici I zato kažem: Prestanimo s takvom praksom! u slučaju kada se predstavnik neke političke stranke obraća biračima, a misli na radnje s kojima treba prestati njegova stranka ili političari općenito.

Imperativ kao gramatička kategorija i imperativnost kao komunikacijski oblik nisu sinonimne pojave. Tradicionalno se smatra kako imperativ najčešce podrazumijeva imperativnost, no ne vrijedi i obrnuto - imperativnost se kao komunikacijski način može, ali i ne mora izraziti gramatičkom formom imperativa ${ }^{3}$. Dakle, imperativnost podrazumijeva ,zapovjednost” u značenju,

\footnotetext{
${ }^{1}$ Vrlo detaljna i sistematično razrađena uporaba imperativa te popis imperativnih oblika u suvremenoj jezičnoj situaciji, ali i onih imperativa koji se danas više ne koriste u svakodnevnoj komunikaciji, a čiji su se relikti zadržali u nekim formulaičnim izrazima (npr. pozdravima, molitvama) nalazi se u Pranjković, Badurina (2012). Stoga ćemo se mi u ovome radu pozabaviti samo onim primjerima imperativa koji bilo u funkcionalnom bilo $u$ formalnom obliku odstupaju od konvencionalnoga gramatičkog opisa.

${ }^{2}$ Više o konstruiranju skupina putem ličnih zamjenica i odnosima moći koje one reflektiraju cf. Katnić-Bakaršić $(2012,54-55)$

${ }^{3} U$ literaturi se mogu pronaći čak i primjeri u kojima se samom imperativu odriče vrijednost glagolskoga načina te ga se poima kao govorni čin. Tako primjerice Dolinina (2001, 501) kaže da ,imperativ nije kategorija glagolskoga načina, kako se tradicionalno poima. On je zapravo kategorija govornoga čina koji izvana uokviruje propoziciju”. Ovdje vidimo pomak s gramatičkoga na pragmalingvistički aspekt, odnosno poimanje glagolskoga načina kao ilokucijske snage. Ne tako izravno, no ipak prema pragmatici imperativa pomaknut
} 
no zapovjedni se komunikacijski efekt nekog iskaza može postići različitim morfosintaktičkim oblicima, primjerice tvrdnjama (Propuh je.) ili pitanjima (Zar ne osjećaš propuh?). U takvim slučajevima od sugovornika očekujemo da ,između redaka“ iščita smisao iskaza, odnosno da ga ne interpretira kao tvrdnju ili pitanje, već kao govornikov zahtjev (molbu, želju, ovisno o komunikacijskoj situaciji), tj. da na temelju općega znanja izvede pravilnu implikaturu. Osim toga, i sam se imperativ može upotrijebiti u situacijama u kojima nikako ne možemo tvrditi da on nosi oznaku imperativnosti u smislu zapovjednosti iskaza - primjerice u savjetima ili molbama.

Dakle, u razmatranjima koja slijede koncentrirat ćemo se na dva aspekta pojedine izjave: gramatičko značenje, odnosno informaciju koja je sadržana u određenom leksičko-sintaktičkom obliku, te propoziciju, odnosno ono što je rečeno. Međutim, ono što je rečeno može se tumačiti na više različitih načina, pa u razmatranje moramo uvesti i kontekst pomoću kojega sužavamo broj mogućih implikatura koje stvaramo na temelju određene propozicije u određenoj situaciji. Da bismo detaljnije pojasnili navedene komunikacijske efekte, prijeko je potrebno pozvati se na interpretaciju lokucije i ilokucije u okviru teorije govornih činova. U tom ćemo kontekstu prvo ukazati na razliku između ilokucijske svrhe i ilokucijske snage, što će nas u nastavku nužno dovesti do razmišljanja o imperativnim značenjima u izrazima bez formalne oznake imperativnosti te o izrazima koji imaju sve formalne oznake imperativa, ali ne i njegovo značenje. Konačno, uporabu ćemo imperativa dovesti u vezu s uljudnošću u komunikaciji.

\section{Govorni činovi s obzirom na ilokucijsku svrhu i ilokucijsku snagu}

Searle je u svojem pokušaju usustavljivanja, tj. klasificiranja govornih činova (ili kako ih on naziva ilokucijskih činova) ukazao na neke

pristup nalazimo i kod autorskoga dvojca Pranjković, Badurina (2012, 620), koji kaže da je kategorija imperativnosti ,,izrazito vezana za govorni čin (...) pa je po tome ipak u tijesnoj vezi (i) s kategorijom modalnosti, i to tzv. subjektivne modalnosti, tj. onog tipa modalnosti koji pretpostavlja između sadržaja komunikacije i sudionika govornog čina". Mi ćemo se u ovome radu ipak držati tradicionalna, gramatičkog poimanja pojma imperativa, a njegov ćemo ilokucijski potencijal nazvati imperativnošću iskaza. 
nedostatke Austinove klasifikacije, pri čemu je uveo 12 kriterija prema kojima se govorni činovi međusobno razlikuju. Pritom su, prema njegovu mišljenju, temeljna tri kriterija razlikovanja ilokucijska svrha, uvjet iskrenosti te sprega između svijeta i riječi, odnosno smjer djelovanja radnje iskazane određenim činom (Searle, 1979, 2-8). Ovim trima kriterijima dodajemo i četvrti po redu Searleov kriterij, naime ilokucijsku snagu, za koju on ne tvrdi izrijekom da je nužna za samu klasifikaciju, no kako ćemo vidjeti, nužna je za komunikaciju, odnosno govornikov odabir verbalnih sredstava kojima želi prezentirati neku svoju zamisao. Drugim riječima, ilokucijska snaga iskaza neki će iskaz na temelju društvenih konvencija klasificirati kao uljudan ili neuljudan, tj. primjeren ili neprimjeren nekoj situaciji. Ilokucijskom se pak svrhom obilježava govornikova namjera, dakle ono što on želi postići nekim svojim verbalnim iskazom.

Uvjet iskrenosti odnosi se na psihološko stanje govornika, odnosno na njegov stav prema radnji sadržanoj u iskazu. Primjerice ako govornik izražava kakvu želju, pretpostavka je da on to doista želi. Drugačije rečeno, ako su sugovornici komunikacijski kooperativni te jedan od njih kaže drugome Želim da sutra dođeš $k$ meni, onda trebamo pretpostaviti da govornik doista želi da sugovornik dođe k njemu. Uvjet iskrenosti za govorne činove koje u sebi sadržavaju karakteristiku imperativnosti jest govornikova želja da se radnja sadržana u prijedlogu izvede.

Sprega između riječi i svijeta sastavnica je zapravo ilokucijske svrhe (Searle, 1979, 3), pa će tako govorni činovi čija je ilokucijska svrha primjerice govornikovo preuzimanje kakve obveze u budućnosti imati smjer sprege u kojemu se svijet prilagođava riječi (odnosno propoziciji iskaza), dok će oni govorni činovi kojima je ilokucijska svrha opis kakve situacije imati smjer sprege u kojemu se riječ prilagođava svijetu. U slučaju govornih činova s karakteristikom imperativnosti smjer je prilagodbe od svijeta prema riječi.

Slijedom rečenoga možemo zaključiti da pri tumačenju govornih činova koji u sebi sadrže indikatore imperativnosti (bilo morfosintaktičke bilo implikaturne, tj. kontekstualne) možemo poći od pretpostavke da govornik njima implicira svoju želju da sugovornik izvrši određenu radnju, što istovremeno znači i želju da se svijet prilagodi radnji naznačenoj u propoziciji izričaja.

Imperativnost podrazumijeva komunikacijsku funkciju zahtijevanja, no jasno je da si u svakodnevnoj komunikaciji često ne možemo priuštiti 
jednostavno slijeđenje Searleovih pravila za izvedbu govornoga čina zahtjeva ${ }^{4}$ jer nam društvene norme nameću svoja ograničenja pri odabiru morfosintaktičkih jedinica kojima iskazujemo vlastite želje. Kako je teorija govornih činova u svojoj srži komunikacijski orijentirana, tako je i Searle u svojim kasnijim promišljanjima u obzir uzeo i one pojavnosti u kojima morfosintaktička reprezentacija nekog iskaza slijedi obrazac pravila za jednu vrstu govornih činova, ali njegovo značenje nema ilokucijsku snagu istoga govornog čina. Dakle, tu dolazimo do situacije u kojoj ne postoji podudarnost formalnoga ustrojstva iskaza i njegove komunikacijske funkcije. Takve iskaze Searle naziva indirektnim govornim činovima te ih opisuje kao „slučajeve u kojima govornik izgovara rečenicu, misli ono što kaže, ali misli i još nešto" (Searle, 1975, 59). Takvi iskazi imaju dvije ilokucijske snage: primarnu i sekundarnu, što znači da predstavljaju iskaze koji sadrže ilokucijsku snagu koja ukazuje na jedan tip govornoga čina, a istovremeno se njima izvodi neki drugi tip govornoga čina (Searle, 1975, 59).

Jedan od najčešćih takvih primjera u svakodnevnoj komunikaciji jest postavljanje zahtjeva u obliku pitanja, primjerice Možete li zatvoriti vrata? Kako vidimo, formalni aspekti takvih iskaza govore nam da je riječ o pitanju, no uzmemo li u obzir gore navedene Searlove kriterije za razlikovanje pojedinih govornih činova, vidjet ćemo da je ilokucijska svrha takvih iskaza govornikova želja da sugovornik izvrši radnju prezentiranu u prijedlogu (zatvaranje vrata), a ne da sazna nešto više o sugovornikovoj mogućnosti ili sposobnosti zatvaranja vrata.

\section{Imperativ bez imperativnosti vs. imperativnost bez imperativa}

Imperativ se, kako smo na početku već naznačili, gramatički opisuje kao glagolski način kojim se izravno obraćamo sugovorniku, no postoje slučajevi u kojima imperativ uopće ne podrazumijeva fizičku prisutnost sugovornika (cf. Schmerling, 1982, 207), pa čak ni to da sugovornik ima semantičku oznaku ,živo”. Takve primjere nalazimo u monološkim iskazima tipa Samo budi visok! (primjerice ako osoba ide na rendez-vouz

\footnotetext{
${ }^{4}$ Više o pravilima za pojedine tipove govornih činova vidi u Searle, 1969, 62-68.
} 
naslijepo) ili Samo nemoj padati! (ako se osoba na primjer nađe na ulici bez kišobrana i ugleda crni oblak).

Međutim, kako smo na početku ovoga rada razmatrali, ne uključuje svaki imperativni oblik oznaku imperativnosti, odnosno nema svaki imperativni oblik svojstvo zapovijedi. Za usporedbu možemo uzeti dva primjera: Brzo dođi! i Brzo ozdravi! Kako vidimo, gramatički su ta dva primjera identična - riječ je, dakle, o imperativu, dok se iz perspektive teorije govornih činova ti primjeri razlikuju u ilokucijskoj svrsi. U prvom je slučaju riječ o direktivu, konkretno o naredbi ili zahtjevu, u kojem govornik od sugovornika zahtijeva izvršenje radnje iskazane u propoziciji, dok je u drugom slučaju riječ o ekspresivu, odnosno govornom činu u kojem se ilokucijska svrha ogleda u iskazivanju govornikova psihološkog stanja u odnosu na neku okolnost. Drugim riječima, sugovornik je bolestan, a govornik mu želi da brzo ozdravi. Ta se želja od govornikove želje u prvom slučaju razlikuje utoliko što je govornik svjestan da u iskazu Brzo ozdravi! sugovornik ne može neposredno izvršiti radnju sadržanu u propoziciji. Dakle, možemo reći i da se ta dva govorna čina razlikuju u perlokucijskom učinku ${ }^{5}$ - u prvom slučaju nema očigledne prepreke za sugovornikovo izvršenje radnje, dok u drugom slučaju nema očite mogućnosti za sugovornikovo izvršenje radnje. Osim toga, drugi primjer ne pretpostavlja govornikov autoritet. Na sličan način možemo tumačiti razliku između imperativa koji sadrže imperativni oblik glagola biti, primjerice Budi miran! u odnosu prema Budi pozdravljen!

U nastavku donosimo još neke oblike u kojima se javlja imperativ bez pragmatičkoga svojstva imperativnosti u smislu ilokucijske snage naređivanja:

Recite mi što da radim. (pitanje, molba)

Uzimajte svakih šest sati po jednu žlicu. (savjet, preporuka)

Molim te, posudi mi 100 kuna. (molba)

Ne izlijevajte tekućinu u plastične cijevi. (upozorenje)

Poslužite se! (ponuda)

Dođi večeras na predstavu. (poziv)

Uštedite i do $5000 \mathrm{kn}$ ! (poticaj)

Idite samo ravno i skrenite u prvu ulicu lijevo. (uputa)

${ }^{5}$ Još je i Austin $(2014,69-75)$ strukturu govornoga čina podijelio na lokuciju, ilokuciju i perlokuciju, a Searle je toj podjeli dodao još i propoziciju i stav (Searle, 1969). Obojica se slažu da se perlokucija ogleda u efektu koji neki iskaz ima na sugovornika. 
Poseban oblik imperativa pronalazimo i u različitim oblicima kletvi, gdje iskazi imaju gramatički oblik imperativa, ali se $\mathrm{s}$ jedne strane ne mogu svrstati u pragmatički razred direktiva (jer im ilokucijska svrha nije izvršenje radnje sadržane u propoziciji), a s druge strane ne odgovaraju ni klasi ekspresiva jer se želja govornika ne podudara s radnjom iskazanom u propoziciji, kao što je slučaj u primjeru Brzo ozdravi!. Primjerice ako se sugovornici svađaju i jedan drugom kaže Crkni!, ne možemo reći da je taj iskaz odraz želje govornika za smrću sugovornika niti da govornik doista očekuje od govornika da izvede radnju/čin crkavanja.

Standardni način uporabe imperativa svakako je izricanje naredbi. No naredbe se mogu izreći i na druge načine, a da pritom ne izgube svoju imperativnost jer ona je njihovo imanentno obilježje. Prema Austinu (2014, 49 ff) brojni se performativni oblici iskaza mogu upotrijebiti u obliku imperativa, štoviše, u svojim je kasnijim razmatranjima o teoriji performativa čak tvrdio da su imperativi zapravo implicitni performativi. Ako primjerice u ispitnoj situaciji profesor kaže Predajte testove!, nedvojbeno je riječ o naredbi iskazanoj imperativnim oblikom, no ako kaže Molim vas, predajte testove!, oblik takva iskaza mogao bi nas navesti na pomisao da je pritom riječ o molbi, no okolinski se čimbenici nisu promijenili - govornik i dalje ima autoritet, želi završiti ispit i očekuje od sugovornika da postupi u skladu s iskazom - pa se unatoč dodanu ilokucijskom indikatoru (molim vas), koji osim prividna ublažavanja naredbe dodaje iskazu i performativnu komponentu, taj iskaz i dalje smatra naredbom. Pritom se može dovesti u pitanje je li to uopće performativ u smislu kako ga je definirao Austin. Naime, upotreba glagola molim u ovom slučaju ne predstavlja i čin imenovanja i čin izvođenja radnje, ako je radnja izvedena iskazom zapravo naredba, a ne molba, odnosno ako je riječ o indirektnom govornom činu. Za usporedbu je govornik mogao reći Naređujem vam, predajte ispit!, gdje bi odabirom glagola koji istovremeno imenuje i izvodi radnju naredbe naglasio svoju poziciju moći ili bi, gledajući iz perspektive uljudnosti, manje uljuđenim načinom obznanio svoju želju, no u biti je u oba slučaja izvedena radnja naredbe uz jasne morfosintaktičke oznake imperativa.

Već smo ranije vidjeli u kakvom su odnosu ilokucijska svrha i ilokucijska snaga pojedinog iskaza, odnosno zaključili smo da se jedna te ista ilokucijska svrha može izraziti putem iskazā različitih ilokucijskih snaga. Ovdje ćemo se osvrnuti na one govorne činove koji se uglavnom 
pod djelovanjem indirektnosti kao temeljnoga zahtjeva teorije uljudnosti putem različitih ilokucijskih snaga upotrebljavaju za verbaliziranje radnji koje u sebi nose komponentu imperativnosti.

Na početku promišljanja o uljudnoj neizravnosti možemo utvrditi sljedeće: želimo li navesti govornika na to da izvrši neku radnju, konvencionalno „propisan” način - koji nam uostalom jamči i najmanju mogućnost pogrešnoga tumačenja naše intencije - jest eksplicitno ukazivanje na tu želju, odnosno uporaba imperativa. Upotrebljavamo li imperativni glagolski način, znamo da postoje morfosintaktička pravila koja moramo uzeti u obzir kako bismo uopće mogli složiti rečenicu za čiji modus možemo reći da je imperativni (znamo primjerice da takvu rečenicu sasvim sigurno nećemo početi s Jesi li slučajno raspoložen za...). Želimo li pak u taj govorni čin uključiti aspekte uljudnoga ophođenja, možda ćemo odabrati ljubazniji način i iskazati svoju želju upitnim rečeničnim modusom, po mogućnosti uz performativnu komponentu „molim te”. U tom slučaju, dakako, polazimo od pretpostavke da naš sugovornik na temelju svoga znanja i, eventualno, prošlih iskustava u komunikaciji s nama iz poruke koja mu je upućena izvede implikaturu o tome što mi zapravo želimo (cf. i Palašić, 2015, 40). Dakle, kako vidimo, a dali smo već i ranije naslutiti, pitanja su jedan od najčešćih oblika izbjegavanja izravnosti u komunikaciji. Oznaka imperativnosti, tj. zahtijevanja nalazi se u srži definicije pitanja - postavljanjem pitanja govornik očekuje odgovor od sugovornika, dakle zahtijeva određenu reakciju. Zanimljivo je, međutim, primijetiti neke specifičnosti unutar same te morfosintaktičke kategorije s obzirom na njezinu funkciju u konkretnom komunikacijskom činu. Pitanja su po svojoj funkciji vrlo bliska imperativnim oblicima, jer i ona uključuju izravno obraćanje sugovorniku. Osim toga, pitanjem govornik sugovorniku daje „do znanja da nešto ne zna, da su mu znanje odnosno obavijest kojima raspolaže u čemu manjkavi ili da nije siguran u ono što zna" (Pranjković, 2013, 17). U kontekstu takva poimanja poseban oblik pitanja s temeljnom oznakom imperativnosti čine tzv. ispitna pitanja (cf. Zimmermann, 1988, 91), kod kojih je evidentno da ona predstavljaju tek uljuđeni oblik postavljanja zahtjeva, $i$ to u obliku upravo ritualizirane interakcije između profesora i studenta - naime ispitivač upravo „glumi” ${ }^{\prime \prime}$ da ne zna odgovor na pitanje, odnosno zahtijeva

${ }^{6}$ Naime, polazeći od Austinove teorije performativa, možemo tvrditi da je svaki institucionaliziran (govorni) čin u svojoj srži određen ulogom koju osoba u određenoj instituciji 
od sugovornika da kaže nešto o temi koju pitanje sadrži. Najbolji indikator te ,glume” pitanja su koja bi po svojoj formi pretpostavljala afirmacijski ili negacijski odgovor, primjerice Znate li nešto o vukovcima? Ispitnom situacijom određen koncepcijski okvir u takvim nam slučajevima pruža informaciju da odgovor nikako ne može biti $D a$. ili $N e$, već da je primjerena reakcija na takvo ,pitanje” odgovarajuća količina informacija o vukovcima.

Osim pitanjem imperativnost može biti izrečena i morfosintaktičkim oblicima koji uključuju futur prvi, a prema kojima bi se iskaz mogao svrstati u razred asertiva (tvrdnji): Doći ćeš kući do 10! Evidentno je da je u takvim slučajevima riječ o indirektnim govornim činovima, gdje je sekundarna ilokucija tvrdnja, a primarna naredba. Isto je i s prezentskim oblicima, primjerice Ti sada ideš kući!, gdje nam kontekst (neravnopravan odnos govornika i sugovornika - govornik ima autoritet - te ostali komunikacijski indikatori poput tona glasa, gestikulacije i sl.) odaje primarnu ilokuciju iskaza, dakle naredbu.

Mogli bismo općenito reći da su iskazi koji u sebi nose indikatore imperativnosti takve komunikacijske radnje kojima govornik pomoću situaciji primjerenih verbalnih sredstava želi navesti sugovornika na neku radnju, pri čemu posreduje iskazom pobuđen osjećaj dužnosti, odnosno komunikacijske kooperativnosti u sugovornika.

\section{Ilokucijska snaga imperativnosti u svjetlu teorije uljudnosti}

Čovjek je kao društveno biće prirodom predodređen za komunikaciju s drugim pripadnicima svoje vrste. U toj se komunikaciji s jedne strane osoba prezentira onako kako želi odnosno smatra da je to pojedinoj komunikacijskoj situaciji primjereno, a s druge strane ostali sudionici komunikacije istu tu osobu percipiraju iz svoje vlastite perspektive odnosno na

ima. U tom smislu govornik u situaciji ispitnih pitanja zapravo igra ulogu ispitivača. Uloga ispitivača podrazumijeva to da osoba koja postavlja pitanja ujedno zna i odgovore na njih, a to je upravo suprotnost klasičnoj definiciji pitanja, prema kojoj govornik ne zna informaciju i njegova je intencija postavljanjem pitanja doći do te informacije. U slučaju ispitnih pitanja govornik zna informaciju, no postavljanjem pitanja zapravo pokušava doći do informacije o tome zna li njegov sugovornik istu tu informaciju. Drugim riječima, ispitivač ritualno ,glumi” neznanje, a ispitanik je svjestan te glume, pa onda i činjenice da postavljeno pitanje nije pitanje, već zahtjev. 
temelju onoga što osoba pokazuje (iz perspektive primaoca) i onoga što misli da pokazuje (iz vlastite perspektive). Drugim riječima, postoje barem dvije slike: ona koju stvara sam pošiljatelj i ona koju drugi stvaraju o njemu. Ta druga slika ono je što su Brown i Levinson (1987) imenovali „pozitivnim obrazom”.

Zadnjih su desetljeća nastali brojni radovi koji u spregu dovode uporabu jezika i međuljudske odnose, pri čemu se brojni od njih oslanjaju na Weberovu teoriju socijalnoga (cf. Schilling, 1999, 10) i Habermasovu (1981) teoriju komunikacijskoga djelovanja, gdje se polazi od intencionalnosti komunikacije, odnosno od pretpostavke da svakom svojom radnjom, bilo verbalnom bilo neverbalnom, želimo nešto postići. Imperativnost je u tom smislu svakako jedan od najboljih pokazatelja intencionalnosti ljudskoga verbalnoga djelovanja. Međutim, vidjeli smo da međuljudska komunikacija uključuje i brojne izvanjezične faktore koji utječu na odabir jezične reprezentacije, pa u svoja razmatranja moramo nužno uključiti i neke aspekte teorije uljudnosti ${ }^{8}$. Pritom ćemo se u skladu s onime na što smo već ukazali u dosadašnjim razmatranjima o izbjegavanju izravnih zahtjeva referirati isključivo na one dijelove teorije uljudnosti koji se odnose na tzv. facework kako ga tumače Brown i Levinson (1987), dakle isključivo na primjereno i uljudno ponašanje s naglaskom na ublažavanje i izbjegavanje svih onih situacija u kojima bi se mogao ugroziti nečiji obraz. Kako smo

${ }^{7} \mathrm{Za}$ razliku od Goffmanova koncepta obraza, koji on definira kao pozitivnu društvenu vrijednost koju osoba potvrđuje u interakciji s drugima (Goffman, 1967, 5), koncept obraza u autorskog dvojca Brown i Levinson $(1987,61)$ ponešto je drukčiji. Naime, oni razlikuju pozitivan i negativan obraz, pri čemu se pozitivan obraz odnosi na govornikovu prezentaciju sebe na način koji će mu osigurati odobravanje i prihvaćanje ostalih članova društva, odnosno pozitivan obraz predstavlja želju za asimilacijom individue u društvu, a negativan obraz odražava govornikovo nastojanje da zadrži svoju individualnost.

${ }^{8}$ Literatura koja se bavi pitanjem uljudnosti bilo iz sociološke bilo iz lingvističke perspektive počela se pojavljivati nakon Goffmanovih djela (1965, Tocka ili ne? i 1967), a postala je gotovo nepregledna nakon djela Politeness. Some universals in laguage usage autorskoga dvojca Brown, Levinson (1987). Niz se knjiga i članaka referira izravno na njihov rad, argumentirajući bilo za bilo protiv teorije univerzalnosti uljudnosti (primjerice Lakoff, Ide [2005]; Fraser [1990]; Thomas [1995] i dr.), no mi se u ovome radu nećemo upuštati u detaljne rasprave oko toga što uljudnost jest ili nije u pojedinom kulturološkom okruženju, već ćemo poći od tvrdnje da svakako postoje iskazi koji se u danoj situaciji mogu smatrati uljudnima ili neuljudnima. Dakle, bez obzira na sve argumente o univerzalnosti principa uljudnosti ovdje ćemo se isključivo baviti pitanjem kako se u određenoj situaciji iz pragmalingvističke perspektive neka izjava može tumačiti s obzirom na kriterij uljudnosti. 
na samom početku ovoga rada istaknuli, najeksplicitniji morfosintaktički oblik iskazivanja imperativnosti jest upotreba imperativa kao glagolskoga načina. Međutim, imperativ se ne smatra nužno najuljudnijim načinom iskazivanja želje, barem ne u slučajevima kada se upotrebljava bez dodatnih modifikacija (poput ilokucijskih indikatora tipa molim) koje bi „otupile" imanentnu mu oštrinu.

U međuljudskoj komunikaciji indirektnost je posve uobičajena, a u nekim je situacijama upravo preferiran oblik verbalne interakcije, iako - paradoksalno - indirektni iskazi zahtijevaju veći stupanj napora u dekodiranju onoga što je govornik htio poručiti ${ }^{9}$. Osim toga, indirektni iskazi sa sobom nose veći stupanj komunikacijskoga rizika (cf. Thomas, 1995, 120) u smislu da povećavaju mogućnost da govornikova namjera (ilokucijska svrha) bude posve pogrešno protumačena, a ponekad će u takvim situacijama upravo načelo uljudnosti spriječiti govornika da korigira sugovornikovu interpretaciju. Stupanj indirektnosti ovisit će o više čimbenika - komunikacijskoj situaciji, odnosu među govornicima, intenciji govornika i sl. ${ }^{10}$

Leech $(1983,136)$ je mišljenja da se izravni zahtjevi općenito smatraju neuljudnima (face-threatening) jer oni „,napadaju” sugovornikov teritorij. Možemo se, dakako, složiti s tvrdnjom da će u većini slučajeva neizravno zahtijevanje ukazivati na veći stupanj uljudnosti. Međutim, postoje s jedne strane situacije u kojima su izravni zahtjevi bez sumnje odraz ljubaznosti, a neizravni uopće ne (kao što, uostalom, postoje i situacije u kojima je neuljudnost poželjna (Leech, 1983, 4) - kada osoba zaslužuje oštriji ton, primjerice u odgojne svrhe). Kako bismo potkrijepili tu tvrdnju, možemo zamisliti situaciju u kojoj zaljubljeni par dogovara mjesto na koje će izići na večeru, te jedno od njih kaže drugome: Ti biraj! Kako vidimo, u tome primjeru imamo vrlo izravno izrečen zahtjev, i to u obliku imperativa, no

${ }^{9}$ Lakoff, Ide $(2005,8)$ mišljenja su da u komunikaciji postoje dvije temeljne strategije: s jedne strane riječ je o maksimi jasnoće (ona se temelji, dakako, na Griceovu principu kooperativnosti), a s druge je strane riječ o maksimi uljudnosti. Međutim, kako smo iz dosad rečenoga vidjeli, te dvije maksime ponekad djeluju u posve suprotnim smjerovima. Veći stupanj izravnosti svakako će pridonijeti poštivanju maksime jasnoće, no u većini slučajeva smanjivat će stupanj komunikacijske uljudnosti, i obrnuto.

${ }^{10}$ Primjerice Kádár i Haugh $(2013,6)$ o uljudnosti govore kao o načinu konstituiranja socijalne prakse te je povezuju s moralnim normama pojedine društvene zajednice. Iz toga se razloga pojmu uljudnosti i može pristupiti iz različitih perspektiva te se njom bave različite znanstvene discipline. 
sasvim sigurno nitko neće tvrditi da je takav iskaz u toj situaciji indikator niskoga stupnja uljudnosti. Leech $(1983,124)$ takve primjere objašnjava pomoću skale „,cost-benefit”, tj. odnosa u kojemu se na jednom kraju nalazi korist za jednoga sugovornika, a na drugome „cijena” te koristi za drugoga sugovornika. Drugim riječima, izravni su zahtjevi u skladu s normama uljudnosti ako njihovo izvršenje predstavlja isključivu korist za sugovornika ${ }^{11}$. U takvu bismo skupinu formalno izravnih, ali funkcionalno uljudnih iskaza mogli uvrstiti i imperative tipa Reci mi kako si, Dođi da ti pomognem ili neke primjere imperativa oblikovanog pomoću čestice da i perfekta: Da se nisi usudio platiti!

S druge pak strane imamo obrnut slučaj, naime iskaze koji svojim formalnim karakteristikama indiciraju iznimno uljudne načine obraćanja, ali nam situacijski indikatori govore suprotno. Možemo primjerice zamisliti situaciju u kojoj se prepiru muž i žena, on izlazi iz kuće, a ona mu kaže Bi li bio tako ljubazan da jednom poneseš i smeće? Jasno je, dakako, da je u ovome ,ljubaznom” upitu skriven ironični prigovor te da bi u takvoj situaciji upravo uljudniji iskaz bio Odnesi usput i smeće!, koji pak svojim formalnim karakteristikama nikako ne bi bio na višoj razini uljudnosti od prethodnoga primjera.

Kako tvrdi Fraser (1990, 22), a potvrđuju gore navedeni primjeri, veći stupanj uljudnosti povezivat ćemo i s većim stupnjem formalnosti, dok će oni oblici koje bismo konvencionalno smatrali uljudnima unutar neke jezične zajednice u kontekstu familijarne, intimne situacije zvučati toliko neobično da ćemo u njima morati potražiti neka dodatna značenja (npr. ironiju, sarkazam), koja će ih svrstati u manje uljudne komunikacijske oblike.

${ }^{11} \mathrm{Na}$ sličan način Leech $(1983,134)$ razmišlja i o različitim stupnjevima uljudnosti te indikatorima koji signaliziraju da je jedan izraz za nijansu uljudniji od drugoga. Tako će primjerice zahtjev izražen pitanjem biti uljudniji od zahtjeva izražena imperativom, ali među zahtjevima izraženima pitanjem uljudniji će biti onaj u kojemu se pitanje formulira tako da se u njemu ne spomene sugovornik kao vršilac radnje, odnosno tako da se u njemu ne referira na „cijenu” koju će radnja imati za sugovornika. Stoga će veća mogućnost za udovoljavanje govornikovu zahtjevu postojati ako on recimo pita Mogu li posuditi tvoju olovku? negoli ako pita Možeš li mi posuditi svoju olovku? 


\section{Zaključak}

U razmatranju formalnih i funkcionalnih obilježja imperativa i imperativnosti u ovome smo radu nastojali razmotriti komunikacijske situacije u kojima imperativ „gubi” konvencionalno mu pripis(iv)ano svojstvo zapovjednoga načina kao i one situacije u kojima se zapovjednost realizira nekim drugim morfosintaktičkim oblicima.

Kako smo u radu već istaknuli, ako svome sugovorniku želimo poručiti da od njega očekujemo neku radnju/neko ponašanje, imperativ je svakako jedan od najjasnijih načina izražavanja koji pritom možemo upotrijebiti. No ako u obzir uzmemo i druge komunikacijske faktore, dakle ne samo sugovornike i poruku, doći ćemo do zaključka da imperativni oblici kodiraju više od samoga zapovjednog načina. Kako je već Austin u svojoj filozofiji svakodnevnoga jezika naglasio, riječi nam osim za opisivanje pojavnosti u svijetu mogu služiti i za vršenje radnji, a imperativni oblici i imperativna značenja zanimljiva su nam upravo u tom kontekstu. Imperativnim oblicima možemo naređivati, zahtijevati, moliti, savjetovati, upozoravati, upućivati, kleti pa čak i pozdravljati ${ }^{12}$.

Iz perspektive teorije govornih činova imperativi ulaze u klasu direktiva, a ta se klasa govornih činova formira oko ilokucijske svrhe koja označava govornikovu želju da se radnja iskazana u propoziciji izvrši (Searle, 1979, 13). Međutim, imperativni oblici, kako se može vidjeti u gore navedenim primjerima u kojima oni ne znače naredbu, ne uključuju uvijek želju govornika da se radnja izvede (primjerice kada je riječ o uputama), no ipak možemo reći da u svakom slučaju indiciraju govornikovo odobravanje radnje iskazane u propoziciji.

Osim imperativa i njihovih mogućih funkcija u radu smo se posvetili i pojmu imperativnosti, odnosno komunikacijskoj funkciji onih iskaza koje sintaktički nećemo označiti kao imperative, ali koji ipak izražavaju ono što se konvencionalno smatra temeljnom imperativnom funkcijom - naime naređivanje ili zahtijevanje. Ti su nam načini iskazivanja imperativnosti posebice zanimljivi s obzirom na društvene norme uljuđenoga

${ }^{12}$ Primjerice Broz $(1885,9)$ navodi niz primjera izravna obraćanja Bogu, od kojih se neki odnose i na razne izreke i želje (Bog daj!), ali neki od njih služe kao pozdravi, npr. Pomoz bog! 
ophođenja, pa smo se u tu svrhu dotaknuli i teorije uljudnosti. Međutim, kako smo pokazali, i modifikatore koji se prema općeprihvaćenom mišljenju koriste za pridavanje uljudne note kakvu iskazu (npr. Bi li bio tako ljubazan..., Molim te..., Bi li možda mogla...) valja razmatrati isključivo u kontekstu konkretne realizacije, pri čemu se osim tih verbalnih u obzir trebaju uzeti i ostali kontekstualni čimbenici (odnos među sugovornicima, situacija u kojoj se govorni čin izvodi, ton glasa, geste i dr.), jer se jedino na temelju ukupne slike može odrediti je li takav iskaz doista uljudniji od eventualno verbalno „neutralnijeg” načina iskazivanja želje ili je on pak odraz ironičnog/sarkastičnog stava govornika.

\section{Literatura}

Austin, J.L. (2014). Kako djelovati riječima. Prev. A. Milanko. Zagreb: Disput.

Brown, P., Levinson S.C. (1987). Politeness. Some universals in language usage. Cambridge: Studies in Interactional Sociolinguistics 4.

Broz, I. (1885). Prilozi za sintaksu jezika hrvatskoga. U: Rad JAZU, knj. LXXVI. Zagreb: JAZU, str. 1-69.

Burkhardt, A. (1990). Speech Act Theory - the decline of a paradigm. U: Speech Acts, Meaning and Intentions. Critical Approaches to the Philosophy of John R. Searle. Ur. A. Burkhardt. Berlin: Walter de Gruyter, str. 91-128.

Bühler, K. (1934). Sprachtheorie. Die Darstellungsfunktion der Sprache. Jena: Gustav Fischer.

Dolinina, I. (2001). The imperativ paradigm: meaning and forms. U: Typology of imperative constructions. Ur. V.S. Khrakovskij, München: Lincom Europas, str. 501-509.

Fraser, B. (1990). Perspectives on Politeness. „Journal of Pragmatics”, vol. 14, br. 3 , str. 219-236. file:///C:/Users/Nikolina/Downloads/Perspectives_on politeness. pdf. 22.09.2017.

Goffman, E. (1967). Interaction ritual. Essays on face-to-face bahavior. New York: Pantheon Books.

Habermas, J. (1981). Theorie des kommunikativen Handelns. Frankfurt am Main: Suhrkamp Verlag.

Kádár, D., Haugh, M. (2013). Understanding politeness. Cambridge: University Press. Katnić-Bakaršić, M. (2012). Između diskursa moći i moći diskursa. Zagreb: Zoro.

Lakoff, R.T., Ide, S. (2005). Broadening the Horizon of Linguistic Politeness. Amsterdam-Philadelphia: John Benjamins Publishing Company.

Leech, G.N. (1983). The Pragmatics of Politeness. London-New York: Longman.

Marot, D. (2005). Uljudnost u verbalnoj $i$ neverbalnoj komunikaciji, „Fluminensia. Časopis za filološka istraživanja", god. 17, br. 1, str. 53-70. 
Palašić, N. (2015). Odnos rečeničnoga modusa i implikatura. „Fluminensia. Časopis za filološka istraživanja", god. 27, br. 2, str. 31-43.

Pranjković, I. (2013). Gramatička značenja. Zagreb: Matica hrvatska.

Pranjković, I., Badurina, L. (2012). Načini izražavanja imperativnosti. U: Bosanskohercegovački slavistički kongres I. Zbornik radova, knjiga 1 (Lingvistika). Ur. M. Omerović, Sarajevo: Slavistički komitet, str. 619-628.

Schmerling, S. (1982). How imperatives are special and how they aren't. U: Papers from the Parasession on Nondeclarative. Ur. R. Schneider, K. Tuite, R. Chametzky. Chicago: Chicago Linguistic Societystr, str. 201-218.

Searle, J.R. (1969). Speech Acts. An Essay in the Philosophy of Language. New York: Cambridge University Press.

Searle, J.R. (1975). Indirect Speech Acts. U: Syntax and semantics, vol. 3. Ur. C. Morgan. New York: Academic Press, str. 59-82.

Searle, J.R. (1979). Expression and meaning. Studies in the Theory of Speech Acts. Cambridge: University Press.

Schilling, U. (1999). Kommunikative Basisstrategien des Aufforderns. Eine kontrastive Analyse gesprochener Sprache im Deutschen und im Japanischen. Tübingen: Max Niemeyer Verlag.

Silić, J., Pranjković, I. (2005). Gramatika hrvatskoga jezika za gimnazije i visoka učilišta. Zagreb: Školska knjiga.

Thomas, J. (1995). Meaning in interaction. An introduction to pragmatics. London-New York: Routledge.

Wunderlich, D. (1976). Studien zur Sprechakttheorie. Frankfurt am Main: Suhrkamp.

Zimmermann, W. (1988). Fragehandlungen und Frageverben. Ein Beitrag zur Vermittlug von Pragmatik, Grammatiktheorie und Lexikographie. Nürnberg: Verlag Palm Enke Erlangen. 